Published in final edited form as:

Contemp Clin Trials. 2013 January ; 34(1): 60-69. doi:10.1016/j.cct.2012.09.004.

\title{
Can Lifestyle Modification Improve Neurocognition? Rationale and Design of the ENLIGHTEN Clinical Trial
}

\author{
James A. Blumenthal, PhD, \\ Duke University Medical Center \\ Patrick J. Smith, PhD, \\ Duke University Medical Center \\ Kathleen Welsh-Bohmer, PhD, \\ Duke University Medical Center \\ Michael A. Babyak, PhD, \\ Duke University Medical Center \\ Jeffrey Browndyke, PhD, \\ Duke University Medical Center \\ Pao-Hwa Lin, PhD, \\ Duke University Medical Center \\ P. Murali Doraiswamy, PhD, \\ Duke University Medical Center \\ James Burke, MD, \\ Duke University Medical Center \\ William Kraus, MD, \\ Duke University Medical Center
}

Alan Hinderliter, MD, and

University of North Carolina at Chapel Hill

Andrew Sherwood, PhD

Duke University Medical Center

\section{Abstract}

\begin{abstract}
Background-Risk factors for cardiovascular disease (CVD) not only increase the risk for clinical CVD events, but also are associated with a cascade of neurophysiologic and neuroanatomic changes that increase the risk of cognitive impairment and dementia. Although epidemiological studies have shown that exercise and diet are associated with lower CVD risk and reduced incidence of dementia, no randomized controlled trial (RCT) has examined the independent effects of exercise and diet on neurocognitive function among individuals at risk for dementia. The ENLIGHTEN trial is a RCT of patients with CVD risk factors who also are
\end{abstract}

\footnotetext{
(c) 2012 Elsevier Inc. All rights reserved.

Corresponding author: James A. Blumenthal, Ph.D., Department of Psychiatry and Behavioral Sciences, Duke University Medical Center, Durham, NC 27710. Tel: (919) 684-3828; Fax: (919) 684-8629; Blume003@ mc.duke.edu.

Publisher's Disclaimer: This is a PDF file of an unedited manuscript that has been accepted for publication. As a service to our customers we are providing this early version of the manuscript. The manuscript will undergo copyediting, typesetting, and review of the resulting proof before it is published in its final citable form. Please note that during the production process errors may be discovered which could affect the content, and all legal disclaimers that apply to the journal pertain.
} 
characterized by subjective cognitive complaints and objective evidence of neurocognitive impairment without dementia (CIND)

Study Design-A 2 by 2 design will examine the independent and combined effects of diet and exercise on neurocognition. 160 participants diagnosed with CIND will be randomly assigned to 6 months of aerobic exercise, the DASH diet, or a combination of both exercise and diet; a (control) group will receive health education but otherwise will maintain their usual dietary and activity habits. Participants will complete comprehensive assessments of neurocognitive functioning along with biomarkers of CVD risk including measures of blood pressure, glucose, endothelial function, and arterial stiffness.

Conclusion-The ENLIGHTEN trial will (a) evaluate the effectiveness of aerobic exercise and the DASH diet in improving neurocognitive functioning in CIND patients with CVD risk factors; (b) examine possible mechanisms by which exercise and diet improve neurocognition; and (c) consider potential moderators of treatment, including subclinical CVD.

\section{Keywords}

Neurocognition; Cognitive impairment; Dementia; Aerobic exercise; Nutrition; DASH diet; CIND; Randomized Clinical Trial

\section{Introduction}

It has been estimated that one in three Americans will experience a stroke, dementia, or both during their lifetimes (1). As the world population ages, the number of older adults developing dementia is estimated to increase from the current 26.6 million to over 106 million by mid-century (1-3) and many more will develop cognitive impairments without meeting criteria for dementia (i.e., CIND), making neurocognitive disorders a national priority (4). The term CIND was first used in the Canadian Study of Health and Aging (1) for individuals whose difficulties with memory or other cognitive domains were not sufficiently severe to meet the diagnostic criteria for dementia, but were judged to be distinct from individuals with normal cognition. Amnestic mild cognitive impairment is generally considered to represent a subset of CIND with distinct memory complaints, while CIND is a broader category that often involves more subtle deficits in executive function, language abilities, and other non-memory cognitive domains that represent the earliest signs of dementia (5-7). Because substantive neuronal losses have already occurred by the time a diagnosis of dementia is made, none of the medical therapies currently available are likely to be able to replace or restore lost nerve cells. Thus, there is a great need to develop strategies to halt or slow the earliest signs of dementia, i.e., CIND, before significant and irreversible neuronal and functional losses have occurred.

It is now widely recognized that known risk factors for CVD, including hypertension, diabetes, and hyperlipidemia, are risk factors not only for CVD events, but also for dementia and late-life cognitive decline $(8,9)$. The ENLIGHTEN trial seeks to examine the impact of diet and exercise, two lifestyle interventions known to reduce CVD risk, as potential approaches to improve neurocognition in patients with CIND who are vulnerable to developing dementia and progressive neurocognitive impairments.

\section{Cardiovascular Disease and Cognitive Function}

It is well established that strokes, lacunar infarcts, and carotid atherosclerosis can lead to cognitive impairment and increase the risk for dementia(10-15), and recently developed dementia risk profiles now include vascular risk factors(16). Neuropathological studies indicate that the pathological changes associated with dementia frequently co-occur with vascular pathology(17). The Rotterdam Study, for example, demonstrated that indices of 
atherosclerosis were associated with both vascular dementia $(\mathrm{VaD})$ and Alzheimer's disease (AD), and that the prevalence of both were associated with atherosclerotic disease (18-20). Half of patients with CVD who develop dementia have AD and more than a third of pathologically confirmed AD patients have evidence of vascular lesions (21). In addition, cerebrovascular risk factor reduction using statins is known to decrease the risk of stroke and may be associated with reduced risk of dementia (22). Furthermore, the effects of VaD and $\mathrm{AD}$ pathologies are additive, and in most population-based samples these conditions cooccur (23-25).

Prospective observations confirm that those individuals with subclinical CVD (determined by intima media thickness [IMT], carotid stenosis, and EKG abnormalities) are more likely to show cognitive decline over five years (26). Structural measures of atherosclerotic burden, such as IMT, and functional measures of endothelial impairment are associated with decrements in cognitive performance in cross-sectional studies (27-29) as well as with cognitive decline in prospective examinations (30-32). It has been suggested that IMT may represent a marker for CVD and generalized atherosclerosis rather than a cause of cognitive impairment (33). Vascular endothelial function provides an important "barometer" of atherosclerotic risk that plays a vital role in the development, progression and clinical manifestations of atherosclerosis (34-37) and can be assessed non-invasively using vascular ultrasound techniques to determine flow-mediated dilatation (FMD) of the brachial artery (38). FMD represents an index that a) has been related to a wide range of CVD risk factors $(35,39), b)$ is predictive of CVD events, including death, MI and stroke (40-43), and c) may be improved both by pharmacological therapies and lifestyle interventions in patients with CVD (44-46). Endothelial dysfunction also has been detected in patients with AD and VaD (47) and is characteristic of dementia (48) and is related to neuropsychological deficits in patients with depression (27) suggesting that endothelial dysfunction may be a common etiologic pathway and biomarker for both disease processes.

Abnormalities in glucose metabolism are also associated with dementia (49-55) and elevated levels of inflammatory markers such as C-reactive protein are associated with more rapid cognitive decline (56), particularly in the presence of the metabolic syndrome (57), and are prospectively related to cognitive impairment (58). Taken together, these is emerging evidence that CVD risk factors are also risk factors for dementia, and that improving CVD biomarkers may be effective in reducing the risk of neurocognitive impairment and dementia (59).

\section{Lifestyle Factors and Neurocognition}

There is growing recognition that lifestyle factors may have important effects on both heart and brain health. Chiuve et al. (60) studied over 114,000 men and women and observed that body mass index $<25 \mathrm{~kg} / \mathrm{m}^{2}$, $>30 \mathrm{~min} /$ day of moderate physical activity, not smoking or drinking alcohol to excess, and scoring in the top $40 \%$ on a healthy diet score were key elements to reduced stroke risk.

Observational studies have shown that physically active individuals perform better on neurocognitive tests compared to their less active counterparts $(61,62)$. Results from interventional studies also indicate that aerobic exercise is associated with improved cognitive functioning, although the evidence is inconsistent(63-68)and studies often exclude patients with cognitive impairments (65). We recently noted that individuals with diminished cognitive abilities and CVD risk factors (i.e., vascular CIND) may achieve greater neurocognitive benefits from lifestyle interventions compared to cognitively intact individuals (69). Two recent studies of patients with cognitive impairment also are relevant: In an Australian study, 170 patients with reported memory problems were randomized to 6 months of home-based physical activity or to an education control (70). Results revealed 
that participants in the physical activity group had better ADAS-cog scores compared to those in the usual care control group and that the benefits were apparent after 6 months and persisted for 12 months. Although these findings are promising, changes in aerobic fitness were not measured, the exercise training program was not documented, and the mechanisms by which exercise produced improvements in neurocognition were not assessed. In another recent RCT of patients with cognitive impairment, Baker et al.(71) demonstrated that 6 months of high intensity aerobic exercise improved executive control processes, with effects more pronounced for women compared to men. Women also showed greater improvements in indices of glucoregulation and insulin sensitivity, suggesting that neurocognitive improvements may be mediated by cardiovascular and metabolic effects of exercise. However, the sample was small $(\mathrm{N}=33)$ and only a completers analysis was reported. Although it has been suggested that exercise may reduce incident dementia by stimulating growth factors and improving cerebrovascular risk factors, the mechanisms responsible for improved neurocognition require further study (72).

The relationship between diet and cognition also has been a topic of increasing interest. Recent studies have shown that variations in dietary practices and nutrient intake are predictive of cognitive decline (73), dementia (74), and AD (75). A number of specific nutrient components of these diets have been examined in relation to cognitive performance including dietary fatty acids and fish oil (76-78), and various supplements such as vitamins E and C (79-81), B6, B12 (82-84), and folate $(85,86)$. However, to date, virtually all RCTs have focused on dietary supplements or nutrients, rather than a 'whole diet' approach, with generally negative or inconsistent results (87). Recent observational studies have shown that the Mediterranean diet is associated with reduced risk of neurocognitive impairment and dementia, and that adherence to this diet may protect against subsequent cognitive dysfunction in a dose-dependent fashion (88). Moreover, Scarmeas(89) recently demonstrated that adherence to a Mediterranean-type diet and physical activity were independently and additively associated with lower risk of developing AD.

The DASH diet is a similar diet that is part of current national recommendations for the prevention and treatment of HTN (JNC-7) (90), which emphasizes low fat dairy products, fruits and vegetables, and reduced fat and cholesterol (91). The DASH diet is effective in reducing $\mathrm{BP}$ in all segments of the population and it is particularly effective in African Americans, a group that is disproportionately affected by CVD and in whom dementia is approximately twice as likely to develop compared to whites $(92,93)$. In a prospective cohort study of 88,517 women nurses adherence to the DASH diet was associated with lower risk of IHD and stroke (94). A subanalysis also found that the DASH diet was associated with lower inflammatory markers associated with IHD. Because of the known benefits of the DASH diet for improving CVD risk factors, independent of weight loss, we propose to examine the impact of the DASH diet alone and combined with aerobic exercise, on neurocognition in patients with CVD risk factors and CIND. Preliminary data from our group have shown that the DASH diet is associated with improved neurocognition, and when combined with exercise, the DASH diet may produce even greater beneficial effects on vascular function and neurocognition (95).

\section{Aims of the ENLIGHTEN Trial}

The ENLIGHTEN Trial is a single-site, RCT sponsored by the National Heart, Lung, and Blood Institute examining the effects of aerobic exercise and the DASH diet on biomarkers of CVD risk and neurocognitive function among adults with vascular CIND. We will examine the following hypotheses:

a. Aerobic exercise and the DASH diet independently will be associated with greater improvements in neurocognitive functioning compared to controls; the effects will 
be additive, with greatest improvements observed in the combined diet and exercise group; (b) Aerobic exercise and the DASH diet independently will be associated with greater improvements in CVD risk factors including (i) BP and vascular stiffness; (ii) Framingham Stroke scores; (iii) subclinical atherosclerosis as assessed by measures of flow mediated dilation (FMD); (iv) inflammation assessed by Creactive protein; and (v) glucose metabolism and insulin resistance; and (3) improvements in vascular function will mediate the relationship between exercise and diet and improved neurocognition.

\section{Research Design and Methods}

One hundred sixty men and women with either CVD or two or more risk factors for CVD who meet eligibility criteria will be randomized to one of four groups for the 26-week intervention to include (a) supervised aerobic exercise, (b) DASH diet, (c) combined supervised exercise and DASH diet, or (d) a health education control group. The study design is depicted in Figure 2. Persons complete written informed consent, are initially screened for CIND and history of CVD or CVD risk factors and, if eligible, undergo a physical examination by the study physician to determine eligibility and safety of participation. Upon completion of the medical and cognitive screening, eligible participants undergo an assessment of cognitive function and cardiovascular biomarkers at baseline and again after 6 months of treatment; patients also undergo another cognitive assessment 18 months after baseline assessment (12 months posttreatment) by an examiner blind to patient group and baseline ratings. Our protocol was approved by the National Institutes of Mental Health and by the Institutional Review Board at Duke University Medical Center.

\section{Participant eligibility}

The following eligibility criteria will allow patients to enter the baseline evaluation phase of the trial: (a) Male or female outpatients $\geq 55$ years of age with at least two traditional CVD risk factors or prior CVD event (myocardial infarction, coronary artery bypass grafting $[\mathrm{CABG}],>70 \%$ stenosis, peripheral vascular disease, or mild stroke without residual deficits), (b) subjective complaints about cognitive abilities [e.g. reduced memory], (c) capacity to give informed consent and follow study procedures, (d) adequate visual and auditory acuity to allow valid neuropsychological testing, (e) and a score between 20 and 25 on the Montreal Cognitive Assessment (MoCA)(96) or letter fluency $\leq 13$ or animal fluency $\leq 15(97)$ and a score $>0.5$ on the Activities of Daily Living questionnaire from the Alzheimer's Disease Cooperative Study (ADCS). All participants (and study partners) will provide written informed consent prior to the screening. In general, CIND patients are able to provide consent for themselves. If there is a question regarding capacity to consent, we also obtain consent for the patient from the patient's designee (power of attorney or designated responsible family member). Consent also will also be obtained from the study partner for their participation in the study (i.e. for their role in completing questionnaires, accompanying patients to their treatment sessions).

\section{Interventions}

Following completion of the baseline assessments, patients will be randomly assigned to (1) Aerobic Exercise (AE) training; (2) the DASH diet; (3) a combination of AE and DASH; or (4) Health Education controls. All conditions will consist of 3 months of face-to-face contact followed by 3 months of home-based treatment. Assignment of patients will proceed using a conditional random assignment plan, with assignment conditional upon gender, age (55-69 or $\geq 70 \mathrm{yrs}$ ) severity of CIND (MoCA scores $20-23$ or $\geq 24$ ), and history of CVD event (presence or absence). 


\section{Aerobic exercise}

Participants will exercise for 6 months. In the initial 3-month supervised phase, patients will exercise 3 times a week at a level of 50-75\% of their initial peak heart rate reserve (HRR) or at their peak heart rate without symptoms, or ST-segment depression $>1 \mathrm{~mm}$, as determined at the time of their initial exercise test. Aerobic exercise consists of 10 minutes of warm-up exercises followed by 30 minutes of continuous walking or (stationary) biking. Each exercise session will conclude with a 10 minute period of cool-down exercises. During weeks 13 to 24 (i.e., home maintenance phase), participants will be asked to perform 3 aerobic sessions per week at home at 60-70\% HRR. We have used home-based exercise in our prior work of older depressed patients(98) and in the HF-ACTION trial(99), in which patients also were transitioned to home-based exercise after 3 months of supervised exercise. Participants in the AE alone condition will not receive any counseling in the DASH diet and will be encouraged to follow their usual diets.

\section{Dietary Approaches to Stop Hypertension (DASH) Diet}

Participants in the DASH condition only receive instruction in modifying the content of their diet to meet DASH guidelines. Participants will be explicitly asked not to exercise and to focus their attention on what they eat. Participants will have been told (in the initial consent form) that the study is designed to study effects of two interventions (altering diet content and exercise) both of which have been shown to improve health. Participants will also be told that it may be easier or more effective for them if they focus first on learning to alter diet content, and they are free to exercise at the end of the 6-month period. Strategies to improve motivation will be used to enhance commitment and confidence for behavior change and to help participants explore and resolve ambivalence $(100,101)$.

\section{Combined aerobic exercise and DASH diet}

Participants in the AE + DASH condition will receive both the Exercise and DASH interventions as described above. This approach of combining treatments has been used successfully in our prior work in which we combined AE and diet (45)in hypertensive adults.

\section{Health education control group}

The Health Education control group will receive weekly 15-min lectures on relevant, healthrelated topics but will not receive instruction in the DASH diet nor will exercise be promoted. These participants will be asked to maintain their usual dietary and exercise habits for 6 months until they are re-evaluated. Each weekly session will address a topic relevant for CIND such as medical and psychosocial aspects of aging, medication use, CVD risk factors, and symptom management. The health educator will follow an outline for each session, and will encourage patients (and their study partners) to ask questions. These sessions are designed to provide useful information about medical aspects of CVD, but will not provide instruction in the DASH diet or exercise. Thus, this control condition will help to minimize the possibility that gains result merely from staff attention or from the active involvement of the study partner in the treatment.

\section{Participant adherence}

Supervising exercise physiologists document exercisers' attendance at each exercise session as well as the modality used during training (i.e., walking on a treadmill, stationary bicycle, etc.). In addition, they record exercisers' heart rate ranges during training and ratings of perceived exertion three times during the exercise session. Participants in both the DASH and combined groups will have their weekly dietary intake recorded and examined by a study dietician. All participants complete a monthly tracking form that inquires about 
changes in health status, medication use, or lifestyle habits (e.g., diet, exercise, etc.). This procedure is designed to determine the occurrence of 'unplanned crossover', e.g., control participants who initiate lifestyle changes or DASH only participants who begin exercising.

\section{Participant safety}

The ENLIGHTEN study will take special precautions to ensure patient safety. Our study neurologist will work closely with the study primary investigator and study psychiatrist on all aspects of patient safety. First, patients will be carefully evaluated. Follow-up data will be reviewed at regular monthly consensus conferences attended by the clinical staff including the study psychiatrist and neuropsychologist. Significant clinical deterioration will be defined as meeting any of the following conditions: 1 ) change in CDR from 0.5 to higher score, clinician or informant report of significant worsening; 2) noncompliance with protocol; 3) emergence of significant psychopathology such as depression or agitation that interferes with the conduct of study or subject safety; 4) new onset medical or neurological problems such as stroke or Parkinson's disease.

Second, we recognize that depression is likely to be present in a subgroup of participants (i.e., vascular depression) and depressive symptoms will be carefully monitored. Any patient who becomes actively suicidal will be dropped from further participation and referred for treatment. Our study coordinator will contact the patient within 72 hours after the referral to ensure that the patient has followed through with the referral. Patients who voluntarily drop out of treatment, or who are unable to complete our protocol will not be replaced, but will be contacted for follow-up assessment. Although we do not anticipate a differential pattern of treatment dropout, our sample size is adequate in the event of differential dropouts. In order to ensure patient safety, the coordinator will also contact patients by telephone at regular intervals throughout the follow-up period.

Third, exercise progression will be gradual, with careful attention to clinical symptoms. Because injury resulting from exercise is an important deterrent to continuing an exercise program, patients will be carefully monitored and the exercise prescription of frequency, intensity and duration will be strictly adhered to(102).

\section{Assessment of intermediate endpoints}

In this study, we will examine changes in important biomarkers of risk (i.e., 'intermediate endpoints') in 'vulnerable' patients with either CVD or risk factors for CVD, as well as CIND. The concept of looking at markers of 'vulnerable plaque' (e.g., endothelial dysfunction), 'vulnerable (thrombogenic) blood' (e.g., markers inflammation), and 'vulnerable vasculature' (e.g., CVD risk factors, such as blood pressure) in combination to identify the 'vulnerable patient' has been advanced by a panel of prominent cardiovascular scientists $(103,104)$. We assess changes in CVD risk factors, (blood pressure and lipids), flow mediated dilation (FMD), markers of inflammation (C-reactive protein and interleukin-6) before and after treatment. These intermediate endpoints tap key dimensions of the 'vulnerable patient' $(2,3)$ and were selected because of: (a) their association with neurocognitive function; (b) their association with adverse cerebrovascular outcomes; and (c) their potential to be modified by treatment, including exercise and/or the DASH diet.

\section{Neurocognitive Function}

While CIND involves a wide range of cognitive deficits that may involve many domains, there is likely to be an impairment in "executive functions" such as slowed information processing, impaired ability to shift attentional sets, and deficits in the ability to hold and manipulate information (i.e., working memory) (Garrett et al., 2004; V. Hachinski et al., 2006; Nyenhuis et al., 2004). We adopted a 45-60 minute neuropsychological battery as 
recommended by the Neuropsychological Working Group for vascular cognitive disorders(105). Assessments will include tests of Executive/Attention (Digit Symbol, Trail Making Test, Stroop Test, Ruff 2 \& 7 Test, Animal Naming, Digit Span), Visuospatial ability (Rey-O), Language/lexical Retrieval (Boston Naming test; Animal Naming, Controlled Oral Word Association Test), and Memory/Learning (HVLT-R, Rey-O, immediate \& delayed recall). The neuropsychological test battery will be administered in a fixed order with alternative forms, in counterbalanced order, to minimize practice effects. The tasks are streamlined with standard discontinuation rules applied to reduce subject frustration and overall burden.

\section{Markers of CVD risk}

1) Blood Pressure-Clinic BP will be assessed by a trained research assistant (blinded to treatment), using the auscultatory method, with a calibrated sphygmomanometer and stethoscope.

2) Framingham Stroke Risk Profile (FSRP)—A modified version of the Framingham Stroke Risk Profile $(106,107)$, a risk assessment tool used to assess the risk of incident stroke, will be used an index of cerebrovascular risk, including SBP, antihypertensive medications, diabetes mellitus, cigarette smoking, CVD, left ventricular hypertrophy, and atrial fibrillation.

3) Glucose and lipids-Glucose and lipids will be obtained from fasting blood samples.

\section{Markers of vascular health}

1) Brachial Artery Flow-Mediated Dilation (FMD)—Our technique for assessing FMD follows procedures first described by Celermajer and colleagues(35) and conforms to current standards established by ACC committee guidelines(38).

2) Arterial stiffness-Pulse wave velocity (PWV), measured using the Complior device (Artech Medical, Pantin, France), will be used as an index of central artery stiffness (108).

3) Carotid Artery Intima-Media Thickness (IMT)—Carotid artery IMT will be assessed by high-resolution B-mode ultrasound imaging of the common carotid arteries.

\section{Measures of chronic inflammation}

Plasma inflammatory biomarkers will be measured by ELISA using commercially available kits. Cytokines will be measured using in vitro enzyme-linked immunosorbent assay (ELISA). Due to its association with neurocognitive functioning (57) and with several CVD risk factors(109), we will examine C-Reactive Protein (CRP) via high-sensitivity kits obtained from American Diagnostica, Inc. (Stamford, CT).

Primary and secondary endpoints-The effect of treatment on the primary endpoint of Executive function will be examined using the generalized linear model in the R software package (http://r-project.org). We will adopt the approach recommended by O'Brien(110), constructing a rank-summed composite variable to represent the executive function endpoint. The components of the executive function composite will be the Digit Symbol, Trail Making Test, Stroop Test, Ruff $2 \& 7$ Test, Digit Span, and Animal Naming measures. The composite approach has advantages over testing multiple individual endpoints, including increased reliability, enhanced precision of the treatment estimate, improved power, and minimization of Type I Error $(111,112)$. The 6-month composite will serve as the response variable. The predictor variables will be specified a priori, with the Exercise 
and DASH interventions as two-level factors, and age, gender, ethnicity, education, MoCA score at baseline, and the pretreatment level of the executive function composite as adjustment covariables. Although we predict that the effect of the two treatments will be additive, we will also examine the Exercise by DASH interaction. If a significant treatment effect is observed for the composite, we will follow up with an examination of the individual neurocognitive tests used to create the composite, with a correction for multiplicity (113).

The secondary 6-month endpoints of the additional neurocognitive measures and biomarkers of risk variables (BP, vascular stiffness, Framingham score, FMD, inflammation, lipids, glucose metabolism and insulin resistance) will be evaluated using generalized linear models in parallel fashion to those evaluating neurocognition. Similarly, we will use the generalized linear model for the measures of quality of life and lifestyle factors (diet and physical activity) and aerobic fitness. Separate models will be estimated for each of these secondary outcomes (with the appropriate composites for the neurocognitive measures), again correcting for multiple testing.

Exploratory analyses-We will examine treatment-related improvements in longer term (i.e., 18-month) neurocognitive functioning, including the transition from CIND to dementia, and quality of life using generalized mixed models, with the 6- and 18-month neurocognitive composites as repeated measures response variables. These models will include the treatment indicators and the aforementioned adjustment covariates. Mediational analyses will proceed using the procedures outlined by Kenny and MacKinnon(114, 115). Formal tests of mediation will be conducted using the indirect effect approach with bootstrapped confidence intervals suggested by Mackinnon(115). Moderator analyses will explore the extent to which the treatment might be differentially effective across subpopulations, adjusting for pretreatment levels of age, ethnicity, baseline neurocognitive function, education, and Framingham Stroke Risk scores. For example, neurocognitive impairment has been shown to predict mortality in men but not in women, and stroke and diabetes predicted mortality independent of neurocognition in women, but not in men (116). In addition, physical activity has been shown to be associated with lower risk of CIND in women, but not in men(117). Therefore, we will consider gender as a potential moderator in our analyses. The etiology of dementia is complex and is not fully understood, but both genetic and environmental factors are involved(118). While evidence suggests that genetic factors are important risk factors for dementia, genes do not account for all the variance in disease expression(119). Our own work in a population cohort of exceptionally long-lived individuals known as the Cache County Memory Study(120) suggests that AD is not an inevitable consequence of age or of the APOE genotype and that nearly $30 \%$ of the population did not develop AD regardless of their APOE genotype. Converging evidence supports the view that lifestyle and environmental factors contribute to symptom onset $(8,9)$ and that genetic factors may also moderate the effects of diet and exercise on neurocognition. We also are interested in whether patients with greater subclinical vascular disease will be differentially responsive to treatment. While this is admittedly an exploratory aspect of our application, pilot data from our laboratory suggest that patients with greater underlying vascular disease (assessed by IMT) could potentially benefit most from diet and exercise(95). The results of these subsample/moderator analyses will be interpreted strictly as exploratory and used to guide further research.

Power Analysis-The effects of primary interest are the main effects for exercise and the DASH diet on the executive function composite at 6 months. Our power estimates are based on the following assumptions: 1) pre-treatment level of the composite, age, gender, and ethnicity as covariates in the model; 2) correlation of 0.4 between the covariates and the outcome; 3) an initial sample size of 160 patients with 20\% attrition at 6 months (i.e., about 32 patients with complete data in each of the 4 cells); 4) an alpha of 0.05 . For a given main 
effect, our sample size will yield a power of about .80 to detect a treatment effect of about . 48 standard deviations, and .90 for an effect of about 0.53 standard deviations. In unpublished analyses of our ENCORE study data support the feasibility of observing effects sizes in this range. Among participants in the lowest tertile of executive function before entering treatment, we observed effects sizes of 0.80 for the combined DASH and exercise/ weight management group (compared to usual care), and over 0.50 for the DASH alone group on a composite of executive function measures. We note that these power estimates are likely to be conservative in that we have used a low correlation estimate between the adjustment covariates and the outcome, and also have not accounted for the additional power that is obtained with methods for imputing missing data(121).

\section{Discussion}

The ENLIGHTEN study has several important innovations in comparison with previous trials. ENLIGHTEN is the first randomized trial to examine the effects of diet and exercise among patients with CIND, a vulnerable patient group known to be at risk for $\mathrm{VaD}$ and $\mathrm{AD}$. Our inclusion criteria are novel in that we are identifying patients both by the presence of $\geq$ 2 cerebrovascular risk factors as well as poor performance on brief cognitive screening measures(97). Because cognitive deficits in CIND are often heterogeneous we feel that using this multi-method identification method provides the most appropriate identification method to capture a generalizable study sample, particularly because the MoCA was designed to identify $\mathrm{MCI}(96)$. In addition, our study will utilize a comprehensive neurocognitive assessment battery, recommended by a recent consensus statement (105).

The ENLIGHTEN study will collect data on intermediate CVD endpoints for a variety of reasons. Because 'hard' neurological end-points, such as dementia, occur relatively infrequently even in clinical populations, it is very difficult for any intervention trial to have adequate power to examine these outcomes. However, we will be collecting sensitive neurocognitive data that has previously been recommended by experts in the field of neurology for the detection of cognitive impairment with a vascular etiology (105). In addition, as we have outlined above, we will collect several measures of CVD risk and vascular health which have been shown to be sensitive to the effects of exercise (45) and are predictive of neurological outcomes (122). In the present study, we will examine changes vascular function as potential mediators of treatment improvements in neurocognitive function. Because vascular function has been shown to be associated with worse neurocognitive prognosis (30) and is modifiable with treatment, we feel that these data provide ideal intermediate endpoints to assess the impact of our intervention on hypothesized mediators of cognitive function. Because experts have advocated a comprehensive assessment of vulnerable patients $(103,104)$ we will assess other intermediate endpoints including inflammation, insulin sensitivity, and lipids.

\section{Conclusions}

There is now ample evidence that CVD risk factors are associated with increased risk of cognitive impairment and dementia in later life, and that lifestyle factors such as diet and exercise exert a protective effect on cognitive function. However, no randomized trials have examined the effects of a combined exercise and dietary intervention on cognitive function among individuals vulnerable to dementia. The ENLIGHTEN study is designed to assess the effects of the DASH diet and aerobic exercise, both independently and in combination, on cognitive function. The study will collect sensitive and clinically validated measures of cognitive function in order to provide a comprehensive assessment of cognition both before and after treatment. The ENLIGHTEN study will also collect sensitive measures of vascular function in order to assess whether improving vascular health may improve cognitive 
outcomes. Finally, we will conduct a follow-up assessment one year after completion of the intervention to examine intervention effects on conversion to dementia. The ENLIGHTEN study promises to provide important information about the value of exercise and the DASH diet in improving cognitive function among individuals with CIND, and will provide insights into the mechanisms by which these interventions may reduce the risk for subsequent development of dementia.

\section{Acknowledgments}

The ENLIGHTEN trial is support by a grant from the National Heart, Lung, and Blood Institute (HL 109219). We also wish to thank Molly McLaren, Julie Johnson, PA-C, Stephanie Mabe, MA, Carola Ekelund, PT, and Kenlyn Young, MS for their involvement in the ENLIGHTEN trial.

\section{References}

1. Graham JE, Rockwood K, Beattie BL, Eastwood R, Gauthier S, Tuokko H, McDowell I. Prevalence and severity of cognitive impairment with and without dementia in an elderly population. Lancet. 1997; 349:1793-6. [PubMed: 9269213]

2. Plassman BL, Langa KM, Fisher GG, Heeringa SG, Weir DR, Ofstedal MB, Burke JR, Hurd MD, Potter GG, Rodgers WL, Steffens DC, McArdle JJ, Willis RJ, Wallace RB. Prevalence of cognitive impairment without dementia in the United States. Ann Intern Med. 2008; 148:427-34. [PubMed: 18347351]

3. Brookmeyer R, Johnson E, Ziegler-Graham K, Arrighi HM. Forecasting the global burden of Alzheimer's disease. Alzheimers Dement. 2007; 3:186-91. [PubMed: 19595937]

4. Melzer D, Ely M, Brayne C. Cognitive impairment in elderly people: population based estimate of the future in England, Scotland, and Wales. Bmj. 1997; 315:462. [PubMed: 9284665]

5. Petersen RC, Smith GE, Waring SC, Ivnik RJ, Tangalos EG, Kokmen E. Mild cognitive impairment: clinical characterization and outcome. Arch Neurol. 1999; 56:303-8. [PubMed: 10190820]

6. Task Force on DSM-IV Diagnostic and statistical manual of mental disorders (DSM-IV-TR). Washington DC: American Psychiatric Association; 2000.

7. Winblad B, Palmer K, Kivipelto M, Jelic V, Fratiglioni L, Wahlund LO, Nordberg A, Backman L, Albert M, Almkvist O, Arai H, Basun H, Blennow K, de Leon M, DeCarli C, Erkinjuntti T, Giacobini E, Graff C, Hardy J, Jack C, Jorm A, Ritchie K, van Duijn C, Visser P, Petersen RC. Mild cognitive impairment--beyond controversies, towards a consensus: report of the International Working Group on Mild Cognitive Impairment. J Intern Med. 2004; 256:240-6. [PubMed: 15324367]

8. Dosunmu R, Wu J, Basha MR, Zawia NH. Environmental and dietary risk factors in Alzheimer's disease. Expert Rev Neurother. 2007; 7:887-900. [PubMed: 17610395]

9. Haan MN, Wallace R. Can dementia be prevented? Brain aging in a population-based context. AnnuRev Public Health. 2004; 25:1-24.

10. Breteler MM. Vascular involvement in cognitive decline and dementia. Epidemiologic evidence from the Rotterdam Study and the Rotterdam Scan Study. AnnNYAcadSci. 2000; 903:457-65.

11. Hachinski VC, Iliff LD, Zilhka E, Du Boulay GH, McAllister VL, Marshall J, Russell RW, Symon L. Cerebral blood flow in dementia. Arch Neurol. 1975; 32:632-7. [PubMed: 1164215]

12. Tatemichi, TK.; Sacktor, N.; Mayeux, R. Dementia associated with cerebrovascular disease, other degenerative diseases, and metabolic disorders. Terry, RD.; Katzman, R.; Bick, KL., editors. New York: Raven Press; 1994.

13. Vermeer SE, Prins ND, den HT, Hofman A, Koudstaal PJ, Breteler MM. Silent brain infarcts and the risk of dementia and cognitive decline. NEnglJMed. 2003; 348:1215-22.

14. Hayden KM, Zandi PP, Lyketsos CG, Khachaturian AS, Bastian LA, Charoonruk G, Tschanz JT, Norton MC, Pieper CF, Munger RG, Breitner JC, Welsh-Bohmer KA. Vascular risk factors for incident Alzheimer disease and vascular dementia: The Cache County Study. Alzheimer Dis Assoc Disord. 2006; 20:93-100. [PubMed: 16772744] 
15. Luchsinger JA, Reitz C, Honig LS, Tang MX, Shea S, Mayeux R. Aggregation of vascular risk factors and risk of incident Alzheimer disease. Neurology. 2005; 65:545-51. [PubMed: 16116114]

16. Kivipelto M, Ngandu T, Laatikainen T, Winblad B, Soininen H, Tuomilehto J. Risk score for the prediction of dementia risk in 20 years among middle aged people: a longitudinal, populationbased study. Lancet Neurol. 2006; 5:735-41. [PubMed: 16914401]

17. Tomlinson BE, Blessed G, Roth M. Observations on the brains of demented old people. J NeurolSci. 1970; 11:205-42.

18. Solfrizzi V, Panza F, Colacicco AM, D'Introno A, Capurso C, Torres F, Grigoletto F, Maggi S, Del PA, Reiman EM, Caselli RJ, Scafato E, Farchi G, Capurso A. Vascular risk factors, incidence of MCI, and rates of progression to dementia. Neurology. 2004; 63:1882-91. [PubMed: 15557506]

19. Breteler MMB, Claus JJ, Grobbee DE, Hofman A. Cardiovascular disease and distribution of cognitive function in elderly people: the Rotterdam study. Bmj. 1994; 308:1604-8. [PubMed: 8025427]

20. Hofman A, Ott A, Breteler M, Bots ML, Slooter A, van Harskamp F, van Duijn CN, Van Broeckhoven C, Grobbee DE. Atherosclerosis, apolipoprotein E, and prevalence of dementia and Alzheimer's disease in the Rotterdam Study. The Lancet. 1997; 349:151-4.

21. de la Torre JC. Is Alzheimer's disease a neurodegenerative or a vascular disorder? Data, dogma, and dialectics. Lancet Neurol. 2004; 3:184-90. [PubMed: 14980533]

22. Menezes AR, Lavie CJ, Milani RV, O'Keefe J. The Effects of Statins on Prevention of Stroke and Dementia: A REVIEW. J Cardiopulm Rehabil Prev. 2012; 32:240-9. [PubMed: 22785147]

23. Snowdon DA. Aging and Alzheimer's disease: lessons from the Nun Study. The Gerontologist. 1997; 37:150-6. [PubMed: 9127971]

24. Rockwood K, Kirkland S, Hogan DB, MacKnight C, Merry H, Verreault R, Wolfson C, McDowell I. Use of lipid-lowering agents, indication bias, and the risk of dementia in community-dwelling elderly people. Arch Neurol. 2002; 59:223-7. [PubMed: 11843693]

25. Jick H, Zornberg GL, Jick SS, Seshadri S, Drachman DA. Statins and the risk of dementia. Lancet. 2000; 356:1627-31. [PubMed: 11089820]

26. Kuller LH, Shemanski L, Manolio T, Haan M, Fried L, Bryan N, Burke GL, Tracy R, Bhadelia R. Relationship between ApoE, MRI findings, and cognitive function in the Cardiovascular Health Study. Stroke. 1998; 29:388-98. [PubMed: 9472879]

27. Smith PJ, Blumenthal JA, Babyak MA, Hoffman BM, Doraiswamy PM, Waugh R, Hinderliter A, Sherwood A. Cerebrovascular risk factors, vascular disease, and neuropsychological outcomes in adults with major depression. Psychosom Med. 2007; 69:578-86. [PubMed: 17634564]

28. Auperin A, Berr C, Bonithon-Kopp C, Touboul PJ, Ruelland I, Ducimetiere P, Alperovitch A. Ultrasonographic assessment of carotid wall characteristics and cognitive functions in a community sample of 59- to 71-year-olds. The EVA Study Group Stroke. 1996; 27:1290-5.

29. Muller M, Grobbee DE, Aleman A, Bots M, van der Schouw YT. Cardiovascular disease and cognitive performance in middle-aged and elderly men. Atherosclerosis. 2007; 190:143-9. [PubMed: 16488420]

30. Wendell CR, Zonderman AB, Metter EJ, Najjar SS, Waldstein SR. Carotid intimal medial thickness predicts cognitive decline among adults without clinical vascular disease. Stroke. 2009; 40:3180-5. [PubMed: 19644063]

31. Slooter AJ, van Duijn CM, Bots ML, Ott A, Breteler MB, De VJ, Wehnert A, de KP, Havekes LM, Grobbee DE, Van BC, Hofman A. Apolipoprotein E genotype, atherosclerosis, and cognitive decline: the Rotterdam Study. JNeural TransmSuppl. 1998; 53:17-29.

32. Haan MN, Shemanski L, Jagust WJ, Manolio TA, Kuller L. The role of APOE epsilon4 in modulating effects of other risk factors for cognitive decline in elderly persons. JAMA: The Journal of the American Medical Association. 1999; 282:40-6. [PubMed: 10404910]

33. Johnston SC, O'Meara ES, Manolio TA, Lefkowitz D, O'Leary DH, Goldstein S, Carlson MC, Fried LP, Longstreth WT Jr. Cognitive impairment and decline are associated with carotid artery disease in patients without clinically evident cerebrovascular disease. AnnInternMed. 2004; 140:237-47. 
34. Anderson TJ, Gerhard MD, Meredith IT, Charbonneau F, Delagrange D, Creager MA, Selwyn AP, Ganz P. Systemic nature of endothelial dysfunction in atherosclerosis. AmJCardiol. 1995; 75:71B4B.

35. Celermajer DS, Sorensen KE, Gooch VM, Spiegelhalter DJ, Miller OI, Sullivan ID, Lloyd JK, Deanfield JE. Non-invasive detection of endothelial dysfunction in children and adults at risk of atherosclerosis. Lancet. 1992; 340:1111-5. [PubMed: 1359209]

36. Najemnik C, Sinzinger H, Kritz H. Endothelial dysfunction, atherosclerosis and diabetes. Acta Med Austriaca. 1999; 26:148-53. [PubMed: 11512191]

37. Bonetti PO, Lerman LO, Lerman A. Endothelial dysfunction: a marker of atherosclerotic risk. Arteriosclerosis, Thrombosis \& Vascular Biology. 2003; 23:168-75.

38. Corretti MC, Anderson TJ, Benjamin EJ, Celermajer D, Charbonneau F, Creager MA, Deanfield J, Drexler H, Gerhard-Herman M, Herrington D, Vallance P, Vita J, Vogel R. Guidelines for the ultrasound assessment of endothelial-dependent flow-mediated vasodilation of the brachial artery: a report of the International Brachial Artery Reactivity Task Force. J Am Coll Cardiol. 2002; 39:257-65. [PubMed: 11788217]

39. Neunteufl T, Maurer G. Noninvasive ultrasound techniques for the assessment of atherosclerosis in coronary artery disease. CircJ. 2003; 67:177-86. [PubMed: 12604862]

40. Heitzer T, Schlinzig T, Krohn K, Meinertz T, Munzel T. Endothelial dysfunction, oxidative stress, and risk of cardiovascular events in patients with coronary artery disease. Circulation. 2001; 104:2673-8. [PubMed: 11723017]

41. Neunteufl T, Heher S, Katzenschlager R, Wolfl G, Kostner K, Maurer G, Weidinger F. Late prognostic value of flow-mediated dilation in the brachial artery of patients with chest pain. American Journal of Cardiology. 2000; 86:207-10. [PubMed: 10913483]

42. Chan SY, Mancini GBJ, Kuramoto L, Schulzer M, Frohlich J, Ignaszewski A. The prognostic importance of endothelial dysfunction and carotid atheroma burden in patients with coronary artery disease. J Am Coll Cardiol. 2003; 42:1037-43. [PubMed: 13678927]

43. Gokce N, Keaney JF Jr, Hunter LM, Watkins MT, Nedeljkovic ZS, Menzoian JO, Vita JA. Predictive value of noninvasively determined endothelial dysfunction for long-term cardiovascular events in patients with peripheral vascular disease. JAmCollCardiol. 2003; 41:1769-75.

44. Esposito K, Marfella R, Ciotola M, Di PC, Giugliano F, Giugliano G, D'Armiento M, D'Andrea F, Giugliano D. Effect of a mediterranean-style diet on endothelial dysfunction and markers of vascular inflammation in the metabolic syndrome: a randomized trial. JAMA: The Journal of the American Medical Association. 2004; 292:1440-6. [PubMed: 15383514]

45. Blumenthal JA, Babyak MA, Hinderliter A, Watkins LL, Craighead L, Lin PH, Caccia C, Johnson J, Waugh R, Sherwood A. Effects of the DASH diet alone and in combination with exercise and weight loss on blood pressure and cardiovascular biomarkers in men and women with high blood pressure: the ENCORE study. Arch Intern Med. 2010; 170:126-35. [PubMed: 20101007]

46. Gokce N, Vita JA, Bader DS, Sherman DL, Hunter LM, Holbrook M, O'Malley C, Keaney JF Jr, Balady GJ. Effect of exercise on upper and lower extremity endothelial function in patients with coronary artery disease. Am J Cardiol. 2002; 90:124-7. [PubMed: 12106840]

47. Zuliani G, Cavalieri M, Galvani M, Passaro A, Munari MR, Bosi C, Zurlo A, Fellin R. Markers of endothelial dysfunction in older subjects with late onset Alzheimer's disease or vascular dementia. J NeurolSci. 2008; 272:164-70.

48. Dede DS, Yavuz B, Yavuz BB, Cankurtaran M, Halil M, Ulger Z, Cankurtaran ES, Aytemir K, Kabakci G, Ariogul S. Assessment of endothelial function in Alzheimer's disease: is Alzheimer's disease a vascular disease? JAmGeriatrSoc. 2007; 55:1613-7.

49. Arvanitakis Z, Wilson RS, Bienias JL, Evans DA, Bennett DA. Diabetes mellitus and risk of Alzheimer disease and decline in cognitive function. ArchNeurol. 2004; 61:661-6.

50. Steen E, Terry BM, Rivera EJ, Cannon JL, Neely TR, Tavares R, Xu XJ, Wands JR, de la Monte SM. Impaired insulin and insulin-like growth factor expression and signaling mechanisms in Alzheimer's disease--is this type 3 diabetes? J Alzheimers Dis. 2005; 7:63-80. [PubMed: 15750215]

51. Watson GS, Craft S. The role of insulin resistance in the pathogenesis of Alzheimer's disease: implications for treatment. CNS Drugs. 2003; 17:27-45. [PubMed: 12467491] 
52. Hayden KM, Warren LH, Pieper CF, Ostbye T, Tschanz JT, Norton MC, Breitner JC, WelshBohmer KA. Identification of $\mathrm{VaD}$ and $\mathrm{AD}$ prodromes: The Cache County Study. Alzheimers Dement. 2005; 1:19-29. [PubMed: 19595812]

53. Launer LJ, Ross GW, Petrovitch H, Masaki K, Foley D, White LR, Havlik RJ. Midlife blood pressure and dementia: the Honolulu-Asia aging study. NeurobiolAging. 2000; 21:49-55.

54. Whitmer RA, Sidney S, Selby J, Johnston SC, Yaffe K. Midlife cardiovascular risk factors and risk of dementia in late life. Neurology. 2005; 64:277-81. [PubMed: 15668425]

55. Cukierman T, Gerstein HC, Williamson JD. Cognitive decline and dementia in diabetes-systematic overview of prospective observational studies. Diabetologia. 2005; 48:2460-9. [PubMed: 16283246]

56. Yaffe K, Lindquist K, Penninx BW, Simonsick EM, Pahor M, Kritchevsky S, Launer L, Kuller L, Rubin S, Harris T. Inflammatory markers and cognition in well-functioning African-American and white elders. Neurology. 2003; 61:76-80. [PubMed: 12847160]

57. Yaffe K, Kanaya A, Lindquist K, Simonsick EM, Harris T, Shorr RI, Tylavsky FA, Newman AB. The metabolic syndrome, inflammation, and risk of cognitive decline. JAMA: The Journal of the American Medical Association. 2004; 292:2237-42. [PubMed: 15536110]

58. Okereke O, Hankinson SE, Hu FB, Grodstein F. Plasma C peptide level and cognitive function among older women without diabetes mellitus. Arch Int Med. 2005; 165:1651-6. [PubMed: 16043685]

59. Casserly I, Topol E. Convergence of atherosclerosis and Alzheimer's disease: inflammation, cholesterol, and misfolded proteins. Lancet. 2004; 363:1139-46. [PubMed: 15064035]

60. Chiuve SE, Rexrode KM, Spiegelman D, Logroscino G, Manson JE, Rimm EB. Primary prevention of stroke by healthy lifestyle. Circulation. 2008; 118:947-54. [PubMed: 18697819]

61. Yaffe K, Barnes D, Nevitt M, Lui LY, Covinsky K. A prospective study of physical activity and cognitive decline in elderly women: women who walk. Arch Intern Med. 2001; 161:1703-8. [PubMed: 11485502]

62. Weuve J, Kang JH, Manson JE, Breteler MM, Ware JH, Grodstein F. Physical activity, including walking, and cognitive function in older women. JAMA: The Journal of the American Medical Association. 2004; 292:1454-61. [PubMed: 15383516]

63. van Uffelen JG, Chin APMJ, Hopman-Rock M, van MW. The effects of exercise on cognition in older adults with and without cognitive decline: a systematic review. Clin J Sport Med. 2008; 18:486-500. [PubMed: 19001882]

64. Heyn P, Abreu BC, Ottenbacher KJ. The effects of exercise training on elderly persons with cognitive impairment and dementia: a meta-analysis. Arch PhysMed Rehabil. 2004; 85:1694-704.

65. Angevaren M, Aufdemkampe G, Verhaar HJ, Aleman A, Vanhees L. Physical activity and enhanced fitness to improve cognitive function in older people without known cognitive impairment. CochraneDatabaseSystRev. 2008:CD005381.

66. Etnier JL, Salazar W, Landers DM, Petruzzello SJ, Han M, Nowell P. The influence of physical fitness and exercise upon cognitive functioning: a meta-analysis. Journal of Sports \& Exercise Psychology. 1997; 19:249-77.

67. Etnier JL, Nowell PM, Landers DM, Sibley BA. A meta-regression to examine the relationship between aerobic fitness and cognitive performance. Brain Res Brain Res Rev. 2006; 52:119-30.

68. Colcombe S, Kramer AF. Fitness effects on the cognitive function of older adults: a meta-analytic study. Psychol Sci. 2003; 14:125-30. [PubMed: 12661673]

69. Smith PJ, Blumenthal JA, Hoffman BM, Cooper H, Strauman TA, Welsh-Bohmer K, Browndyke JN, Sherwood A. Aerobic exercise and neurocognitive performance: a meta-analytic review of randomized controlled trials. Psychosom Med. 2010; 72:239-52. [PubMed: 20223924]

70. Lautenschlager NT, Cox KL, Flicker L, Foster JK, van Bockxmeer FM, Xiao J, Greenop KR, Almeida OP. Effect of physical activity on cognitive function in older adults at risk for Alzheimer disease: a randomized trial. JAMA: The Journal of the American Medical Association. 2008; 300:1027-37. [PubMed: 18768414]

71. Baker LD, Frank LL, Foster-Schubert K, Green PS, Wilkinson CW, McTiernan A, Plymate SR, Fishel MA, Watson GS, Cholerton BA, Duncan GE, Mehta PD, Craft S. Effects of aerobic 
exercise on mild cognitive impairment: a controlled trial. Arch Neurol. 2010; 67:71-9. [PubMed: 20065132]

72. Ahlskog JE, Geda YE, Graff-Radford NR, Petersen RC. Physical exercise as a preventive or disease-modifying treatment of dementia and brain aging. Mayo Clin Proc. 2011; 86:876-84. [PubMed: 21878600]

73. Wengreen HJ, Munger R, Nelson C, Corcoran C. Prospective study of the DASH- and the Mediterranean-style dietary patterns and age-related cognitive change. J Nutr Health Aging. 2011 In Press.

74. Luchsinger JA, Mayeux R. Dietary factors and Alzheimer's disease. Lancet Neurol. 2004; 3:57987. [PubMed: 15380154]

75. Essink-Bot ML, Pereira J, Packer C, Schwarzinger M, Burstrom K. Cross-national comparability of burden of disease estimates: the European Disability Weights Project. BullWorld Health Organ. 2002; 80:644-52.

76. Morris MC, Evans DA, Bienias JL, Tangney CC, Bennett DA, Aggarwal N, Schneider J, Wilson RS. Dietary fats and the risk of incident Alzheimer disease. Arch Neurol. 2003; 60:194-200. [PubMed: 12580703]

77. Morris MC, Evans DA, Bienias JL, Tangney CC, Bennett DA, Wilson RS, Aggarwal N, Schneider J. Consumption of fish and n-3 fatty acids and risk of incident Alzheimer disease. Arch Neurol. 2003; 60:940-6. [PubMed: 12873849]

78. Kalmijn S, Feskens EJ, Launer LJ, Kromhout D. Polyunsaturated fatty acids, antioxidants, and cognitive function in very old men. Am J Epidemiol. 1997; 145:33-41. [PubMed: 8982020]

79. Zandi PP, Anthony JC, Khachaturian AS, Stone SV, Gustafson D, Tschanz JT, Norton MC, Welsh-Bohmer KA, Breitner JC. Reduced risk of Alzheimer disease in users of antioxidant vitamin supplements: the Cache County Study. Arch Neurol. 2004; 61:82-8. [PubMed: 14732624]

80. Masaki KH, Losonczy KG, Izmirlian G, Foley DJ, Ross GW, Petrovitch H, Havlik R, White LR. Association of vitamin $\mathrm{E}$ and $\mathrm{C}$ supplement use with cognitive function and dementia in elderly men. Neurology. 2000; 54:1265-72. [PubMed: 10746596]

81. Engelhart MJ, Geerlings MI, Ruitenberg A, van Swieten JC, Hofman A, Witteman JC, Breteler MM. Dietary intake of antioxidants and risk of Alzheimer disease. JAMA: The Journal of the American Medical Association. 2002; 287:3223-9. [PubMed: 12076218]

82. Malouf R, Areosa SA. Vitamin B12 for cognition. Cochrane Database SystRev. 2003:CD004326.

83. Malouf R, Grimley EJ. The effect of vitamin B6 on cognition. Cochrane Database SystRev. 2003:CD004393.

84. Malouf R, Grimley EJ. Folic acid with or without vitamin B12 for the prevention and treatment of healthy elderly and demented people. Cochrane Database SystRev. 2008:CD004514.

85. Wang HX, Wahlin A, Basun H, Fastbom J, Winblad B, Fratiglioni L. Vitamin B(12) and folate in relation to the development of Alzheimer's disease. Neurology. 2001; 56:1188-94. [PubMed: 11342684]

86. Clarke R, Smith AD, Jobst KA, Refsum H, Sutton L, Ueland PM. Folate, vitamin B12, and serum total homocysteine levels in confirmed Alzheimer disease. Arch Neurol. 1998; 55:1449-55. [PubMed: 9823829]

87. Smith PJ, Blumenthal JA. Diet and neurocognition: review of evidence and methodological considerations. Curr Aging Sci. 2010; 3:57-66. [PubMed: 20298171]

88. Scarmeas N, Stern Y, Mayeux R, Luchsinger JA. Mediterranean diet, Alzheimer disease, and vascular mediation. Arch Neurol. 2006; 63:1709-17. [PubMed: 17030648]

89. Scarmeas N, Stern Y, Mayeux R, Manly JJ, Schupf N, Luchsinger JA. Mediterranean diet and mild cognitive impairment. Arch Neurol. 2009; 66:216-25. [PubMed: 19204158]

90. Chobanian AV, Bakris GL, Black HR, Cushman WC, Green LA, Izzo JL Jr, Jones DW, Materson BJ, Oparil S, Wright JT Jr, Roccella EJ. Seventh report of the Joint National Committee on Prevention, Detection, Evaluation, and Treatment of High Blood Pressure. Hypertension. 2003; 42:1206-52. [PubMed: 14656957]

91. de Souza RJ, Swain JF, Appel LJ, Sacks FM. Alternatives for macronutrient intake and chronic disease: a comparison of the OmniHeart diets with popular diets and with dietary recommendations. AmJ ClinNutr. 2008; 88:1-11. 
92. Tang MX, Cross P, Andrews H, Jacobs DM, Small S, Bell K, Merchant C, Lantigua R, Costa R, Stern Y, Mayeux R. Incidence of AD in African-Americans, Caribbean Hispanics, and Caucasians in northern Manhattan. Neurology. 2001; 56:49-56. [PubMed: 11148235]

93. Svetkey LP, Simons-Morton D, Vollmer WM, Appel LJ, Conlin PR, Ryan DH, Ard J, Kennedy BM. Effects of dietary patterns on blood pressure: subgroup analysis of the Dietary Approaches to Stop Hypertension (DASH) randomized clinical trial. Arch Intern Med. 1999; 159:285-93. [PubMed: 9989541]

94. Fung TT, Chiuve SE, McCullough ML, Rexrode KM, Logroscino G, Hu FB. Adherence to a DASH-style diet and risk of coronary heart disease and stroke in women. Arch Intern Med. 2008; 168:713-20. [PubMed: 18413553]

95. Smith PJ, Blumenthal JA, Babyak MA, Craighead L, Welsh-Bohmer KA, Browndyke JN, Strauman T, Sherwood A. Effects of the dietary approaches to stop hypertension diet, exercise, and caloric restriction on neurocognition in overweight adults with high blood pressure. Hypertension. 2010; 55:1331-8. [PubMed: 20305128]

96. Nasreddine ZS, Phillips NA, Bedirian V, Charbonneau S, Whitehead V, Collin I, Cummings JL, Chertkow H. The Montreal Cognitive Assessment, MoCA: a brief screening tool for mild cognitive impairment. J AmGeriatrSoc. 2005; 53:695-9.

97. Canning SJ, Leach L, Stuss D, Ngo L, Black SE. Diagnostic utility of abbreviated fluency measures in Alzheimer disease and vascular dementia. Neurology. 2004; 62:556-62. [PubMed: 14981170]

98. Blumenthal JA, Babyak MA, Doraiswamy PM, Watkins L, Hoffman BM, Barbour KA, Herman S, Craighead WE, Brosse AL, Waugh R, Hinderliter A, Sherwood A. Exercise and pharmacotherapy in the treatment of major depressive disorder. Psychosom Med. 2007; 69:587-96. [PubMed: 17846259]

99. O'Connor CM, Whellan DJ, Lee KL, Keteyian SJ, Cooper LS, Ellis SJ, Leifer ES, Kraus WE, Kitzman DW, Blumenthal JA, Rendall DS, Miller NH, Fleg JL, Schulman KA, McKelvie RS, Zannad F, Pina IL. Efficacy and safety of exercise training in patients with chronic heart failure: HF-ACTION randomized controlled trial. JAMA: The Journal of the American Medical Association. 2009; 301:1439-50. [PubMed: 19351941]

100. Miller, WR.; Rollnick, S. Motivational interviewing: Preparing people for change. New York: Guilford Press; 1991.

101. Rollnick, SM.; WR; Butler, CC. Motivational interviewing in health care: helping patients change behavior. New York, London: Guilford Press; 2008.

102. Pollock ML, Gettman LR, Milesis CA, Bah MD, Durstine L, Johnson RB. Effects of frequency and duration of training on attrition and incidence of injury. MedSciSports. 1977; 9:31-6.

103. Naghavi M, Libby P, Falk E, Casscells SW, Litovsky S, Rumberger J, Badimon JJ, Stefanadis C, Moreno P, Pasterkamp G, Fayad Z, Stone PH, Waxman S, Raggi P, Madjid M, Zarrabi A, Burke A, Yuan C, Fitzgerald PJ, Siscovick DS, de Korte CL, Aikawa M, Juhani Airaksinen KE, Assmann G, Becker CR, Chesebro JH, Farb A, Galis ZS, Jackson C, Jang IK, Koenig W, Lodder RA, March K, Demirovic J, Navab M, Priori SG, Rekhter MD, Bahr R, Grundy SM, Mehran R, Colombo A, Boerwinkle E, Ballantyne C, Insull W Jr, Schwartz RS, Vogel R, Serruys PW, Hansson GK, Faxon DP, Kaul S, Drexler H, Greenland P, Muller JE, Virmani R, Ridker PM, Zipes DP, Shah PK, Willerson JT. From vulnerable plaque to vulnerable patient: a call for new definitions and risk assessment strategies: Part I. Circulation. 2003; 108:1664-72. [PubMed: 14530185]

104. Naghavi M, Libby P, Falk E, Casscells SW, Litovsky S, Rumberger J, Badimon JJ, Stefanadis C, Moreno P, Pasterkamp G, Fayad Z, Stone PH, Waxman S, Raggi P, Madjid M, Zarrabi A, Burke A, Yuan C, Fitzgerald PJ, Siscovick DS, de Korte CL, Aikawa M, Airaksinen KE, Assmann G, Becker CR, Chesebro JH, Farb A, Galis ZS, Jackson C, Jang IK, Koenig W, Lodder RA, March K, Demirovic J, Navab M, Priori SG, Rekhter MD, Bahr R, Grundy SM, Mehran R, Colombo A, Boerwinkle E, Ballantyne C, Insull W Jr, Schwartz RS, Vogel R, Serruys PW, Hansson GK, Faxon DP, Kaul S, Drexler H, Greenland P, Muller JE, Virmani R, Ridker PM, Zipes DP, Shah PK, Willerson JT. From vulnerable plaque to vulnerable patient: a call for new definitions and risk assessment strategies: Part II. Circulation. 2003; 108:1772-8. [PubMed: 14557340] 
105. Hachinski V, Iadecola C, Petersen RC, Breteler MM, Nyenhuis DL, Black SE, Powers WJ, DeCarli C, Merino JG, Kalaria RN, Vinters HV, Holtzman DM, Rosenberg GA, Wallin A, Dichgans M, Marler JR, Leblanc GG. National Institute of Neurological Disorders and StrokeCanadian Stroke Network vascular cognitive impairment harmonization standards. Stroke. 2006; 37:2220-41. [PubMed: 16917086]

106. Wolf PA, D'Agostino RB, Belanger AJ, Kannel WB. Probability of stroke: a risk profile from the Framingham Study. Stroke. 1991; 22:312-8. [PubMed: 2003301]

107. D'Agostino RB, Wolf PA, Belanger AJ, Kannel WB. Stroke risk profile: adjustment for antihypertensive medication. The Framingham Study Stroke. 1994; 25:40-3.

108. Asmar R, Benetos A, Topouchian J, Laurent P, Pannier B, Brisac AM, Target R, Levy BI. Assessment of arterial distensibility by automatic pulse wave velocity measurement. Validation and clinical application studies. Hypertension. 1995; 26:485-90. [PubMed: 7649586]

109. Dos santos MG, Pegararo M, Macuco EC. Risk factors for the development of atherosclerosis in childhood and adolescence. Arquivos Brasileiros de Cardiologia. 2008; 90:263-83.

110. O'Brien PC. Procedures for comparing samples with multiple endpoints. Biometrics. 1984; 40:1079-87. [PubMed: 6534410]

111. Comelli M, Klersy C. Different methods to analyze clinical experiments with multiple endpoints: a comparison of real data. Journal of Biopharmaceutical Statistics. 1996; 6:115-25. [PubMed: 8732908]

112. LaVange LM, Durham TA, Kolasa KM. Randomization-based nonparametric methods for the analysis of multicentre trials. Stat Methods Med Res. 2005; 14:281-301. [PubMed: 15969304]

113. Lehmacher W, Wassmer G, Reitmeir P. Procedures for two-sample comparisons with multiple endpoints controlling the experimentwise error rate. Biometrics. 1991; 47:511-21. [PubMed: 1912258]

114. Baron RM, Kenny DA. The moderator-mediator variable distinction in social psychological research: conceptual, strategic, and statistical considerations. J PersSoc Psychol. 1986; 51:117382.

115. Mackinnon DP, Lockwood CM, Hoffman JM, West SG, Sheets V. A comparison of methods to test mediation and other intervening variable effects. PsycholMethods. 2002; 7:83-104.

116. Schultz-Larsen K, Rahmanfard N, Kreiner S, Avlund K, Holst C. Cognitive impairment as assessed by a short form of MMSE was predictive of mortality. J ClinEpidemiol. 2008; 61:122733.

117. Middleton L, Kirkland S, Rockwood K. Prevention of CIND by physical activity: different impact on VCI-ND compared with MCI. J Neurol Sci. 2008; 269:80-4. [PubMed: 18243244]

118. Ertekin-Taner N. Genetics of Alzheimer's disease: a centennial review. Neurol Clin. 2007; 25

119. Plassman, BL.; Steffens, DC. Textbook of Geriatric Psychiatry. Washington, DC: American Psychiatric Association; 2004.

120. Khachaturian AS, Corcoran CD, Mayer LS, Zandi PP, Breitner JC. Apolipoprotein E \{epsilon 4 count affects age at onset of Alzheimer Disease, but not lifetime susceptibility: The Cache County Study. Archives of General Psychiatry. 2004; 61:518-24. [PubMed: 15123497]

121. Soullier N, de La Rochebrochard E, Bouyer J. Multiple imputation for estimation of an occurrence rate in cohorts with attrition and discrete follow-up time points: a simulation study. BMC Medical Research Methodology. 2010; 10:79. [PubMed: 20815883]

122. Cechetto DF, Hachinski V, Whitehead SN. Vascular risk factors and Alzheimer's disease. ExpertRevNeurother. 2008; 8:743-50. 


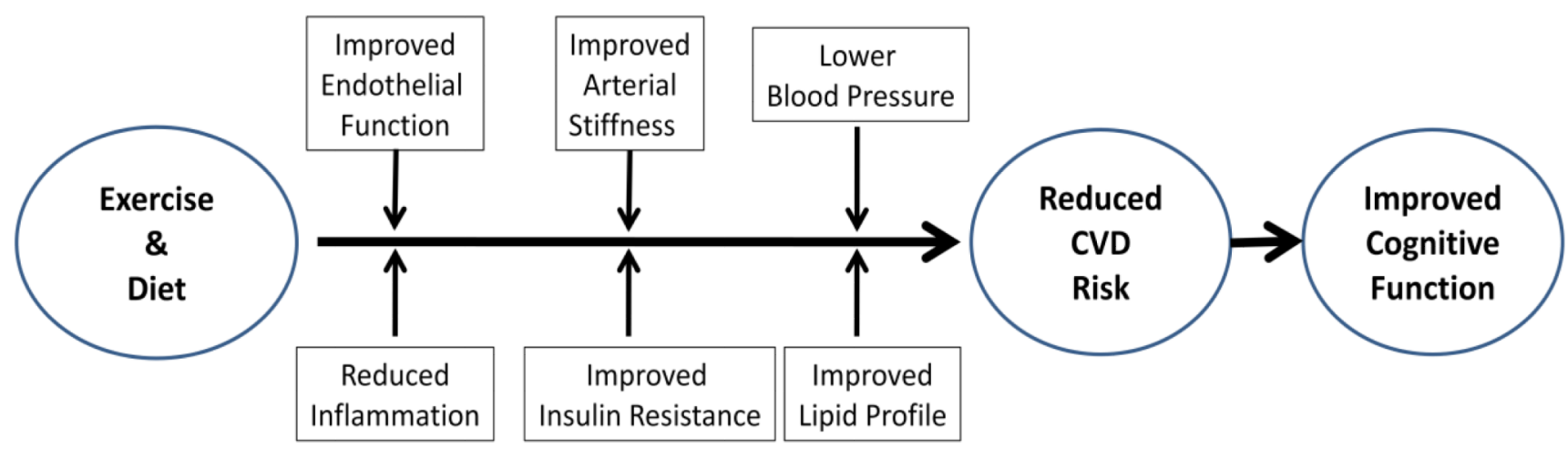

Figure 1.

illustrates how aerobic exercise and diet may enhance neurocognitive function by reducing CVD risk factors. This model is consistent with the notion that a healthy vascular system maximizes the brain's overall functioning and cognitive reserve. Compromised blood flow due to atherosclerosis, vascular stiffening, or endothelial dysfunction may lead to reduced cerebral perfusion and ineffective clearance of waste. Regardless of whether the relation is due to shared risk factors or to direct and indirect influences of CVD on brain pathology, exercise and dietary interventions designed to reduce CVD risk factors are plausible strategies to prevent, slow, or even reverse cognitive decline in vulnerable patients with CVD risk factors and CIND. 


\section{Study Design}

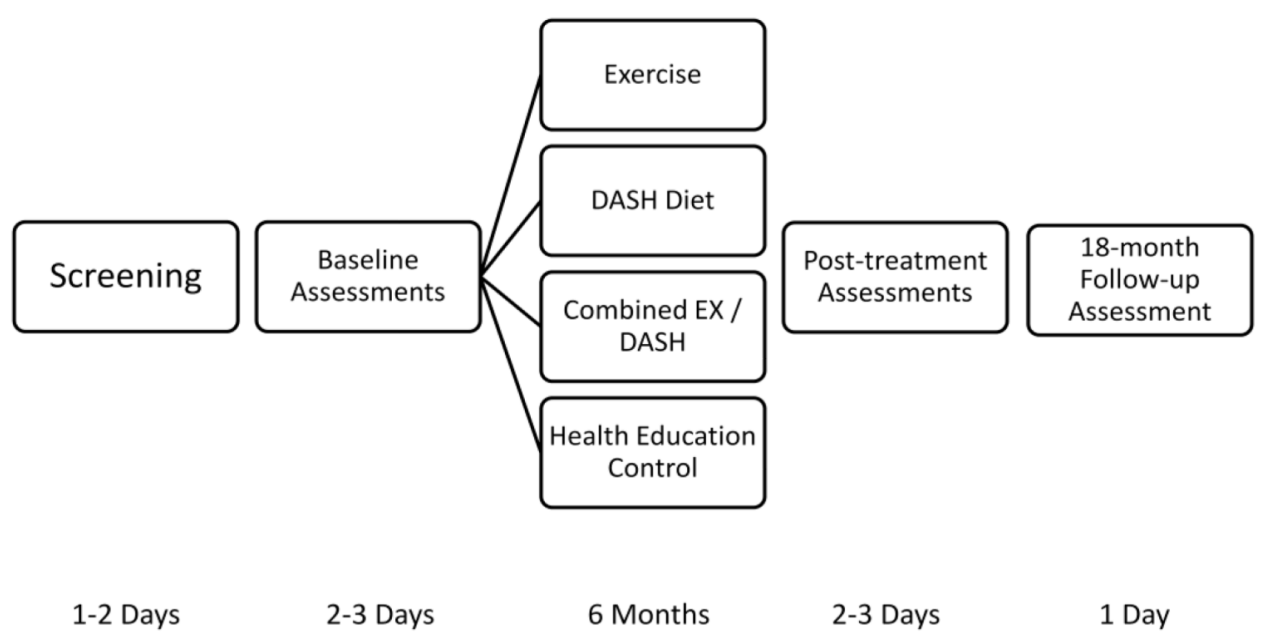

Figure 2.

illustrates the timeline of study assessments and interventions. Using a $2 \times 2$ design, participants will be randomized to receive aerobic exercise, the DASH diet, a combined exercise and DASH diet intervention, or a health education control group for six months. Assessments of cognitive function and CVD risk factors will be conducted at baseline, following six months of intervention, and again one year following completion of the intervention. 